\title{
Understanding Ta-Nehisi Coates' Rejection of Hope
}

\author{
Maanvi Dhillon
}

$\mathbb{R}^{\mathrm{s}}$ EADing Ta-Nehisi Coates' book Between the World and $M e$ is a jarring experience - through and through, it deviates from the common template of a memoir. Coates' storytelling conveys his familiarity with the vast and historical injustices experienced by Black Americans, both through heartwrenching personal anecdotes and informative references, to systems and structures like the racial wealth gap and American mass incarceration. Though the book was published in 2015, it remains a deeply relevant and timely contribution; many Americans continue to be ignorant of the scope and depth of racial inequality in their country. This ignorance was brought to focus during the summer of 2020, when multiple murders of Black Americans by police officers gained international attention, including the murder of George Floyd in Minneapolis [Bennett et al., 2020]. While the Black Lives Matter movement and prison abolitionists have pointed to the American police's racism and violence for years, these cases seemed to finally penetrate the broader consciousness of non-Black Americans, and they participated in protests of an unprecedented scale across the country [Buchanan et al., 2020]. The momentum appeared to spread far, as anti-Black racism was confronted in a myriad of places from professional sports to universities to celebrity social media feeds. Some observed how responses to the protests included superficial, symbolic gestures like corporate statements of solidarity and the removal of stat- ues depicting racist figures, without accompanying substantive change ([Brown, 2021], [Taylor, 2021], [Moore, 2020]). However, much of the surrounding rhetoric characterized the summer as a tipping point, a reckoning, and a dramatic pivot in the public's support of movements for racial justice. This tendency of American popular discourse to extract a narrative of hope and progress from the summer's protests happens to provide a fascinating illustration of the themes and messages in Coates' memoir. What is most striking about his work, and what has fuelled critique from some readers, is his explicit rejection of hope. Coates' decision not to cater to the American audience's craving for optimistic stories has been judged for dampening the motivation people need to fight for racial equality.

Coates' decision to reject hope should be evaluated with a more strategic lens, keeping in mind the nuanced intentions of a writer with such a powerful voice. A crucial aspect of this text is the various audiences that it speaks to: though he formatted the text as a message for his son, Coates would have expected the work to generally reach both Black Americans and white Americans. In this essay, I will use literary analysis to argue that Coates' renouncement of hope is two-pronged, and that his book contains different messages for his various audiences. I will argue that when Coates denounces the hope associated with the American dream, he is addressing his general audience - most specifically, those who have ben- 
efitted from or were bought into the American dream ("Dreamers") - which are white and privileged Americans. However, Coates addresses Black Americans and prioritizes their well-being and survival when he suggests not to have a hope that is conditional on ending racism in America, which I will explain using the literary and cultural theorist Lauren Berlant's contributions to affect theory from their book Cruel $O p$ timism. Overall, Coates makes the important point that the fight for equality is a painful one, and that Black people risk their health, safety, and happiness for an impossible cause if they alone carry the burden of liberating themselves against structures of entrenched racial power and privilege in the US.

To begin, Coates' text contains a searing indictment of the national narrative of hope in the United States known as the American dream, the suggestion that the fairness and vast opportunity available in American society allow any hard worker to succeed and climb to a position of financial security. Coates labels the idyllic outcome of this narrative as the "the Dream", which he describes as "perfect houses with nice lawns... Memorial Day cookouts, block associations, and driveways...treehouses and the Cub Scouts" (11). An important criticism Coates levels towards the Dream regards its implication that wealthy and privileged Americans have earned their progress through their own hard work, when much of the success of white Americans can be traced to the exploitation and oppression of Black Americans. Coates uses several examples to show the consistency of this trend, with the most prominent being slavery. While the American dream is meant to channel America's spirit as a young, scrappy colony that built its way to the top of the global economy with hard work, Coates debunks this myth by reminding readers that America's economy began with the stolen labour of Black people:

At the onset of the Civil War, our stolen bodies were worth four billion dollars, more than all of American industry, all of American railroads, workshops, and factories combined, and the prime product rendered by our stolen bodies - cotton - was America's primary export. The richest men in America... made their riches off our stolen bodies... The soul was the body that fed the tobacco, and the spirit was the blood that watered the cotton, and these created the first fruits of the American garden $(101,104)$.

Coates goes on to prove the "tradition" of Americans exploiting Black people for their own profit by citing examples such as the modern private prison system, where prison operators earn profit from incarcerating a disproportionately large number of Black Americans, thus turning "the warehousing of Black bodies into a jobs program... and lucrative investment for Dreamers" (132). These examples contradict the hope weaved into the American dream by exposing the fact that exploitation is inextricable from evidentiary cases of American industry growth and economic mobility. Coates persuasively refutes the idea that white American success is pure and uncontaminated by the country's historical and ongoing oppression of Black Americans. By repeatedly exposing examples of profit produced by the unjust mistreatment of Black Americans, Coates challenges the classic association between hard work and good character that helps to sustain the American Dream. Coates uproots the core of the American dream myth, which should compel successful and privileged Dreamers to rethink the apparent truthfulness and justice of the hope narrative they have subscribed to.

Furthermore, the flip side of the personal responsibility implied by the American dream is that like success, failure is earned, and people living in poor conditions have only themselves to blame. Coates rejects this implication by connecting the struggles of Black life in America to the actions of white Americans. For example, the mass American public has paid much attention to the murders of innocent Black men by American police officers; these 
are always blamed on errors of the victims, like "Eric Garner's anger" or "Trayvon Martin's mythical words", but the frequency of these incidents and their unprovoked nature suggests that the murders are the product of widespread racist attitudes and reflect the fear that many Americans harbour toward Black men ([Ta-Nehisi, 2015] 78, 96). Coates also references how ghettos like those in north Chicago, which are often Black-dominated areas, were not created naturally but instead "engineered by government policy" (131). For instance, redlining was a government practice that classified the risk of providing credit to people based on geographic location and, due to racist attitudes, resulted in neighbourhoods with mostly Black people being denied home loans and avoided by investors [Jan, 2018]. Even though Dreamers created ghettos, Black people suffered, and continue to suffer, the consequences of cyclic poverty and high crime in such areas. Thus, to blame them for "Black-on-Black" crime in these communities is to ignore the orchestration of ghettos by white Americans and "[vanish] the men who engineered the covenants, who fixed the loans, who planned the projects, who built the streets and sold red ink by the barrel" ([Ta-Nehisi, 2015]; 110, 111). One of Coates' most profound observations is that growing up in such neighbourhoods impedes Black people in a less obvious way by forcing them to spend so much time and mental energy on the task of simply ensuring their own safety (24). All of these impediments contribute to a cycle that makes it incredibly difficult for young Black people to escape the conditions they were born into; as Coates writes, "We could not get out. The ground we walked was tripwired. The air we breathed was toxic. The water stunted our growth. We could not get out" $(27,28)$. In sum, Coates disputes the notion that Black people are responsible for problems plaguing their communities, and in doing so he provides more reasons to reject the American dream and its brand of hope.

Overall, by refuting the notion that American success is justly earned through innocent hard work, and instead connecting their economic success to racial inequality and the oppression of Black people, Ta-Nehisi Coates makes a strong case against the hope of the American dream. While this message might be directed at all readers, Coates' writing seems to suggest something more strategic. For example, when discussing the inherent connection between the struggles of Black communities and the success of white communities, Coates mentions that "[he] knew, as all Black people do, that this fear was connected to the Dream out there" (29). He also explains how he once "wanted to escape into the Dream, to fold [his] country over [his] head like a blanket" but being ignorant was never possible because "the Dream rests on our backs, the bedding made from our bodies" (11). In these statements, Coates appears to acknowledge that most Black Americans are aware of the Dream's falsity because, like Coates, they witness the constant contradictions between the Dream's suggestions and their lived realities. They learn over the course of their lives that despite the Dream's claim of equality, they have to work twice as hard as their white peers, and despite the Dream's claim of reciprocity, their success is always bound by some limit ([Ta-Nehisi, 2015], 90). So, the task of learning to relinquish the Dream is not as urgent for Black Americans as it is for white Americans, who manage to go their whole lives with their heads under the blanket of the American dream and completely buy into its premises. In other words, Coates' message is for the Dreamers who allowed Flint's water crisis, who call the police on Black people doing ordinary things, and who believe they have earned their wealthy, comfortable, safe, and white lives in a vacuum and consequently have no moral obligation to care about the problems of Black Americans. Coates' arguments demonstrate that a crucial condition for the liberation of Black Americans is for white Americans to acknowledge the injustice tainting the American dream hope narrative and work to change the structures and 
power imbalances that perpetuate these conditions.

This leaves an important question to address: what is Coates' message for Black Americans? Between the World and Me has an explicitly named audience - Coates' son Samori - and the language often positions Coates in unity with the reader, using words like "our" and "we". While the text may be framed as being specifically for his son, the audience Coates addresses so intimately can also be interpreted as all Black Americans. Writing as a father, Coates' priority is the safety and wellbeing of his child, which are constantly threatened by the effects of racism. Even though the novel contains lessons ranging from American history to Black activism, the overall tone seems to be advisory rather than merely informative; he is advising his son on how to survive, and flourish, given the nature and realities of his country. Coates' paternal tone makes his lack of optimism about America's ability to achieve racial equality deeply telling and meaningful. While we might want to believe that hope for racial equality would be the best attitude for anybody, Coates argues that having hope would be detrimental to his son, and by extension, to other Black Americans.

To understand why Coates rejects this kind of hope, we must first consider the facts he establishes about the possibility of liberating Black Americans. This includes a hard truth about the fight for racial equality: that Black Americans cannot make it happen by themselves. Coates is firm in his belief that liberating themselves, entirely on the basis of their own efforts, is not a viable option for Black people or oppressed peoples in general and provides no historical evidence as a strategy ([Ta-Nehisi, 2015], 96). The point is especially salient when Coates recalls the story of a peer at Howard University named Prince Jones who was killed by a police officer. Coates met with Prince's mother and learned about how she sent him to private school, bought him a car, took him travelling, and raised him to be an intelligent, wellliked boy, and yet even such privilege and careful nurturing could not protect him from the racist act that ended his life ([Ta-Nehisi, 2015]; 64, 81). While reflecting on the tragedy, Coates affirms his stance on Black Americans' limited abilities to save each other and themselves from the unrelenting and pervasive forces of racism; he writes, "We are captured brother, surrounded by the majoritarian bandits of America... and the terrible truth is that we cannot will ourselves to an escape on our own" (146). He notes that Black activists and movements have accepted this truth, and their goal appears to be "to awaken the Dreamers, to rouse them to the facts of what their need... to think that they are white... has done to the world" (146). However, Coates believes that external efforts to wake up the Dreamers are futile and given their large numbers, power, wealth and everything else that privileges them over Black people only the Dreamers themselves can put a halt to the injustice and oppression that is fed by their lifestyles ([Ta-Nehisi, 2015], 151).

Coates goes on to acknowledge the bleak chances of white Americans voluntarily departing with the superiority that racist structures and systems provide them. He recognizes that many Dreamers would never explicitly state their comfort with the suffering of Black people, but that they are vehemently attached to the privilege this suffering affords them: "very few Americans will directly proclaim that they are in favour of Black people being left to the streets. But a very large number of Americans will do all they can to preserve the Dream" (33). Since they are uncomfortable with this suffering, but refuse to give up their Dream, they resort to willfully forgetting the inherent connection between these realities: "The forgetting is... another necessary component of the Dream. They have forgotten the scale of theft that enriched them in slavery; the terror that allowed them, for a century, to pilfer the vote; the segregationist policy that gave them their suburbs. . because to remember would tumble them out of the beautiful Dream" (143). Coates also believes that the pro- 
cess of gaining from Black suffering has become habit for Dreamers, and so even if they were to recognize the injustice caused by their success, they might prefer the status quo because they are addicted to the formula of easy and cheap gains, which he likens to the "seductiveness of cheap gasoline" (150). Overall, Coates' arguments make it difficult to have faith in the possibility that white Americans will develop the strength and selflessness needed to give up the Dream and its associated racism.

A question underlies Coates' discouraging arguments: in these conditions of systematic inequality and oppression, what happens when Black people continue to invest themselves and their energy into a hope that the Dreamers will wake up and they will eventually be liberated? Coates' answer to this question is that Black people are harmed in this scenario, and maintaining hope is no neutral or easy act, but can be exhausting, disappointing, and dangerous. He explains how resisting the Dream is burdensome for Black people because it leads to "[their] country telling [them] the Dream is just, noble, and real, and [they] are crazy for seeing the corruption and smelling the sulphur" (106). Constantly having their fear and anger brushed off can cause them to lose confidence in their critique, and Coates suggests this can drive Black people to ironically undo their own realization of the lies of the American dream, and instead buy into the idea that they are responsible for their communities' issues (106). Additionally, Coates tells the story of a young Black boy who was shot by a white man after defending himself and refusing to turn down his music - when reflecting on the story, the boy's mother, who taught her son to stand up for himself, wonders "Had he not spoke back, spoke up, would he still be here?" (114). The boy had the right to stand up for himself, and his refusal to submit could have led that white man to realize that they were on equal footing and that this young Black man had no obligation to obey him, but the tragic result of his murder calls the ultimate worth of this stand into question. The fact that the man was not charged for the murder speaks volumes - Black people's protests cannot compete with the authoritative voice of a justice system that permits the murder of Black Americans ([Ta-Nehisi, 2015], 112). This is why Coates feels ashamed rather than proud of a story in which he stood up to a white woman who pushed his son, as he knows his anger could have jeopardized the lives of him and his family if the police were called (95). Furthermore, many parts of the book detail how emotionally draining it can feel to constantly experience the disappointment of dashed hopes, from Coates' sadness after he fails to teach a reporter about the severity of racial injustice in America, to his son's sadness when Michael Brown's killer was not indicted $(11,12)$. These cases exemplify how much the labour of hope takes from Black Americans, from their confidence in their beliefs, to their lives, to their happiness. The logic of rejecting hope is to assert that Black people are not obligated to make these sacrifices.

To better understand Coates' rejection of hope, we can think about hope for racial equality as an instance of Lauren Berlant's theory of cruel optimism. Berlant's work is a famous contribution to affect theory, which are theories considering effects experienced by humans that cannot be captured in typical modes of representation and signification ([Grossberg, 2010], 318). Lisa Blackman expands on this element of affect in her description: "Affect refers to those registers of experience which cannot be easily seen, and which might variously be described as non-cognitive, trans-subjective, non-conscious, nonrepresentational, incorporeal and immaterial" (4). Due to its incompatibility with typical methodologies for interpreting meaning like language and sight ([Blackman and Venn, 2010], 9), affect is often characterized as escaping or existing in excess of traditional representational thinking; Lawrence Grossberg provides the description of "a gap between what can be rendered meaningful or knowable and what 
is nevertheless livable" (318), and Kathleen Stewart refers to "a gathering place of accumulative dispositions...not meaning gathered into codes but the gathering of experience beyond subjectivity, a transduction of forces, a social aesthetics attuned to the way a tendency takes on consistency, or a new regime of sensation becomes a threshold to the real" (340). Citations of and contributions to affect studies are found in fields ranging from philosophy to psychoanalysis to cultural studies [Arthur, 2020], though they generally consider similar questions about embodied experiences and the forces beyond conscious knowing that move people ([Schaefer, 2019]; [Seigworth and Gregg, 2010]). These forces of affect have also been described as "intensities" by the prominent theorist Brian Massumi, which helps us to imagine affect as a process or motion, something that is felt but cannot be directed or structured (86). Massumi articulates how the effect and resonance of intensity may not be logically connected to some content or representation, as meaning and affect operate on different levels ([Massumi, 1995], 84-85; [Blackman and Venn, 2010], 17). The impacts of affects are innumerable, as they may be forces that "serve to drive us toward movement, toward thought and extension, that can likewise suspend us (as if in neutral) across a barely registering accretion of force-relations, or that can even leave us overwhelmed by the world's apparent intractability" [Seigworth and Gregg, 2010]. Affect is crucially considered an "analytic of power" [Arthur, 2020], as it attends to the "capacities to affect and to be affected" ([Stewart, 2010], 339; [Evans, 2017]). The concept of affect seems similar to emotion, but actually varies from emotion's subjective and internal, personal form ([Massumi, 1995], 88). Affect is often described as extending outside the bounding of a single body and being necessarily relational - passing between bodies and each other or the world ([Blackman and Venn, 2010], 21; [Blackman and Venn, 2010], 1-2).
Lauren Berlant's theory of cruel optimism considers how affect can function to keep us in relationships and positions that detract from our wellbeing. As Berlant describes, "a relation of cruel optimism exists when something you desire is actually an obstacle to your flourishing" (1). Any attachment to something desired is optimistic - whether it be food, a lover, sex, patriotism - and we often form these attachments in pursuit of a vision of "the good life" ([Berlant, 2011]; $2,25)$. Berlant explains that affect is the force that draws us back to the object of attachment; though it may be experienced as any feeling, ranging from anxiety to happiness, "the affective structure of an optimistic attachment involves a sustaining inclination to return to the scene of fantasy that enables you to expect that this time, nearness to this thing will help you or a world to become different in just the right way" (2). However, the relation becomes cruel when the object we depend on blocks the very thriving that we sought and that brought us to it in the first place ([Berlant, 2011], 25). For example, Berlant frames the fantasy of upward mobility in America as a cruel optimism. They note that because of economic trends driven by post Second World War neoliberal policies, like deepening inequality, people have grown to adjust to a state of collective and ongoing crisis, or "crisis ordinariness" (10), and Berlant tracks affective responses to the conditions of this age (15-16) and its atmospheres of "anxiety, contingency, and precarity" (19). The continued pursuit of good life fantasies that are no longer possible to attain leads people to enter a self-destructive relationship: they work so much that they do not have time for intimate relationships, they exhaust their bodies, and they become reliant on unhealthy habits to cope with their stressful lives ([Berlant, 2011]; 28, 96-119, 192-222). Berlant argues that when we invest our endurance and our willingness to go on in these varying forms of good life fantasies and their beautiful promises, we "enable a concept of the later to suspend questions about the cruelty of the now" (28). Turning back 
to Coates' memoir, it appears that the cruel optimism relation is precisely what Coates seeks to avoid by advising his son, and other Black people, against hope about improving racial equality in the US: he does not want them to recklessly or frequently subject themselves to the cruelty of the now for the sake of a just future that hinges on white people waking up from their Dream. If Black people turn the fantasy of racial equality into "an anchor for [their] optimism about life", they might be devastated when it is not realized, because when "a relation in which you've invested fantasies of your own coherence and potential breaks down, the world itself feels endangered" [Berlant, 2012].

With this perspective in mind, Coates' intentions gain a sharp new clarity in passages like the following: "you cannot arrange your life around... the small chance of the Dreamers coming into consciousness. Our moment is too brief. Our bodies are too precious" (146). Or, “... do not struggle for the Dreamers. Hope for them... But do not pin your struggle on their conversion" ([Ta-Nehisi, 2015], 151). Coates gives his audience permission to resist the affective pull of the fantasy of hope. He urges them to prioritize their safety, health, wellbeing, love, and time over their labour to convert the Dreamers, and while he is not barring them from doing that work, he releases them of the burden to sacrifice so much for the sake of correcting another group's unjust behaviour. This supports a generalizable point about progress for marginalized communities: sometimes, the responsibility to bring about equality is borne solely by oppressed groups in a world where they lack the power to make required societal changes. The work of maintaining hope is taxing and risky in such conditions. Members of an oppressed community must anticipate the possibility that they may be so worn and emptied out from their fight for justice that they cannot enjoy the flourishing and happy lives that a future, tenta- tive, and hard-fought equality would make possible for them. Coates asks a brave and critical question to Black Americans: is hope worth its cruel cost?

In conclusion, Ta-Nehisi Coates makes cases for hope that vary between the parts of his audience: while he provides evidence that urges white Americans to wake up from the hope of the American dream, he also instructs his son, and I argue, his entire Black audience, not to sacrifice themselves for the sake of hoping for racial equality in America. While his message may seem unhelpful or negative, Lauren Berlant's theory of cruel optimism reveals why we can view hope with skepticism and recognize its harmful potential when it subjects us to destructive processes and when the impossible or unlikely fantasy attached to our hope lies too close to our hearts. Evidenced by this book and his continued presence in conversations about race in America, Coates has not given up on making activist contributions and fighting for the liberation of Black Americans. However, he does so with pragmatism instead of hope because the cause of converting white people to new attitudes is not more important than protecting himself and his family, and because having hope and living as though the Dreamers will wake up has proven to be too costly for Black people.

Interestingly, the rare notes of optimism in Coates' and Berlant's writing intersect, as both suggest solidarity as an alternative to hope and as a source of realness in contrast to hope's artificiality ([Berlant, 2011], 266; [Ta-Nehisi, 2015], 69). While neither writer dwells on the point, perhaps this supplies the "missing incentive" in their pessimistic works: that instead of constantly looking to the future, we should relish and endure life in the present, together. Paying attention to the people around us might be a promising way to step out of the unjust and deceiving fantasies that have so much power in governing our lives.

\section{Author Biography}


Maanvi Dhillon recently graduated from McMaster University's Arts \& Science program. She is interested in political theory, literature, and all the spaces between the two, which is why she was thrilled to examine Ta-Nahisi Coates' work in this essay. While seeking to analyze the nuance and intention of Coates' pessimistic tone in his memoir, she found relevant insights in Lauren Berlant's affect theory. This essay brings those works together to explore the idea of hope in Coates' work. Maanvi is grateful to JIRR for the opportunity and support they have provided in sharing her work. 


\section{References}

[Arthur, 2020] Arthur, M. (2020). Affect studies. Oxford Bibliographies Online in Literary and Critical Theory.

[Bennett et al., 2020] Bennett, D., Lee, J., and Cahlan, S. (2020). The death of george floyd: What video and other records show about his final minutes. Washington Post, 30.

[Berlant, 2011] Berlant, L. (2011). Cruel optimism. Duke University Press.

[Berlant, 2012] Berlant, L. (2012). On her book cruel optimism. Rotoroko. http://rorotoko. com/interview/20120605_berlant_lauren_on_cruel_optimism.

[Blackman and Venn, 2010] Blackman, L. and Venn, C. (2010). Affect. Body \& society, 16(1):7-28.

[Brown, 2021] Brown, R. A. (2021). Opinion: Juneteenth as a national holiday is symbolism without progress. https://www.npr.org/2021/06/19/1008123408/ juneteenth-national-holiday-symbolism-without-progress-opinion.

[Buchanan et al., 2020] Buchanan, L., Bui, Q., and Patel, J. K. (2020). Black lives matter may be the largest movement in us history. The New York Times, 3.

[Evans, 2017] Evans, B. (2017). Histories of violence: Affect, power, violence- the political is not personal: Brad evans interviews brian massumi.

[Grossberg, 2010] Grossberg, L. (2010). 14 Affect's Future. Duke University Press.

[Jan, 2018] Jan, T. (2018). Redlining was banned 50 years ago. it's still hurting minorities today. Washington Post, 28.

[Massumi, 1995] Massumi, B. (1995). The autonomy of affect. Cultural critique, (31):83-109.

[Moore, 2020] Moore, D. (2020). Statues vs. systemic change: How much of a difference does tearing down monuments really make. The Boston Globe.

[Schaefer, 2019] Schaefer, D. O. (2019). The evolution of affect theory: The humanities, the sciences, and the study of power. Cambridge University Press.

[Seigworth and Gregg, 2010] Seigworth, G. J. and Gregg, M. (2010). An Invention of Shimmers. Duke University Press.

[Stewart, 2010] Stewart, K. (2010). Afterword: Worlding Refrains. Duke University Press.

[Ta-Nehisi, 2015] Ta-Nehisi, C. (2015). Between the world and me. Spiegel and Grau.

[Taylor, 2021] Taylor, K.-Y. (2021). Did last summer's black lives matter protests change anything? https: //www.newyorker.com/news/our-columnists/did-last-summers-protests-change-anything. 